\title{
USING CLOUD TECHNOLOGIES AS A TOOL IN ORGANIZING THE EDUCATION PROCESS
}

\author{
Aigul Sadvakassova, ${ }^{1}$ Meryert Serik, ${ }^{2}$ Jaroslav Kultan ${ }^{3}$
}

\begin{abstract}
The transition towards innovative cloud computing technologies will allow universities to reduce the costs of purchasing software licenses and expensive computer parks with large amounts of memory and disks, since the programs used in training sessions, as well as all the results of work done, can be stored in the cloud. The transfer of educational services to the cloud will facilitate switching to a format of "learning everywhere and all the time". This article considers the pedagogical possibilities of cloud technologies, which confirm the expediency of use in the education process. The definition of cloud computing is discussed. In addition, the main task of the research was considered: using cloud technologies as a tool in the organizing education process. The experience of using open source software in training is given. The basic methods of using cloud technology in the learning process are presented.
\end{abstract}

UDC Classification: 004.75; DOI: http://dx.doi.org/10.12955/cbup.v5.1028

Keywords: cloud computing, cloud storage, open-source software, education process

\section{Introduction}

Contemporary computing experiments aimed at solving a great number of important practical tasks require the usage of huge computer capacities. For instance, tasks requiring computing capacities include: precise long-term forecasts of climate changes, genetic engineering, physical processes, chemical reactions and modeling of financial calculations; the auto industry, oil- and gas extraction; pharmacology; circuitry engineering; new materials synthesis; geological cataclysms, and many others. The solution to the aforementioned tasks requires knowledge in concurrent programming, in the architecture of modern multiprocessor computers; systems software of parallel computers and networks; technology of parallel computers programming; parallel algorithms, dispersed data, client-server technology; grid technology, simulation, mathematic foundations of parallel programming; GPU and cloud computing.

Integration of contemporary information technologies into education enables users to achieve plans only in the case of stable, safe and productive functioning of the entire IT infrastructure (Pang, 2009). It has to meet the increasing requirements of increased productivity and fail-safety with constant increase of the processed information volumes. Simultaneously, requirements are set to reduce expenses on support and development of the IT infrastructure and enhance its adaptability to changing requirements to the IT of educational institutions. The most effective means of satisfying those requirements is IT development relying on cloud-based computing, which represents one of the most promising innovative IT trends.

\section{Cloud technologies as an instrument of organizing the learning process}

The ideal goal of cloud computing lies in granting remote dynamic access to end-users for services, computing resources and applications (including operating systems and infrastructure) via the internet. The development of hosting services (hosting is a service of a hosting client's equipment in a provider's territory with a provision of connection to high-capacity channels), was stipulated by the demand for software and digital services capable of being managed from within, yet more cost-effective and efficient.

The concept of cloud computing has largely altered the traditional approach to delivery, management and integration of applications. In comparison to a traditional approach, cloud computing enables running bigger infrastructures, serving various groups of users within a single cloud, and implies dependence on a cloud services provider.

Cloud computing in informatics is a model of providing overall and convenient network access on demand for common computing resources (for instance, data-transmission networks, servers, data storage units, application programmes and services - both altogether and separately), which can be

\footnotetext{
${ }^{1}$ Faculty of Information Technology, L.N. Gumilyov Eurasian National University, sak79@bk.ru

${ }^{2}$ Faculty of Information Technology, L.N. Gumilyov Eurasian National University, serik_meruerts@mail.ru

${ }^{3}$ Faculty of Informatics, University of Economics in Bratislava, jkultan@ gmail.com
} 
promptly provided and relinquished with minimum operating cost and/or addresses to the provider (Sklejter, 2010).

The main distinction of cloud computing lies in the irregularity of users' requests for resources. In order to smooth out this irregularity and provide service, an additional layer is placed between real hardware and middleware, i.e. virtualization of servers. Middleware control is the software ensuring monitoring of equipment's state, load balancing, and provision of resources for problem solution (Sarrab et al., 2015). Servers that run applications get virtualized and load balancing gets performed both through the software and the means of allocating virtual servers, real servers.

\section{Experience of cloud technologies introduced into the learning process}

Cloud technologies ensure optimization of such activities as collection, systematization, storage, retrieval, processing and presentation of information, are of general academic significance and can be applied in studies of all educational disciplines. Implementation of cloud technologies into the learning process is of great value since the latter can increase study hours without changing the curricula of educational institutions.

At the given stage, the integration of the given technology into the learning process and education is underway and has already yielded favorable results. The teaching staff of the L.N.Gumilev Eurasian National University has been engaged in this issue at the university, i.e. setting up a cluster of highperformance parallel computing on the basis of available computers and networking equipment, using it for solving resource-intensive tasks and introducing cloud-based technologies (Serik \& Bajgaraeva, 2014). Scientists of the Russian Federation, Slovak Republic and our university have been dealing with this problem for recent years (Voevodin \& Zhumatij, 2007; Kopyltsov et al., 2010; Schmidt, 2016). Joint articles were published (Kopyltsov et al., 2014; Serik et al., 2016).

Scientists from our country and abroad (the Russian Federation, USA, People's Republic of China, and the Slovak Republic) have acquainted themselves with some of the surveys' results. Partially the results have already been used at the leading universities of the aforementioned countries and received positive responses.

At the Faculty of Information-Processing Technologies of L.N.Gumilev ENU special courses on the subject under study have been introduced into the learning process (three course credits) at all levels of instruction. For instance, in the process of the learning discipline "Fundamentals of cloud technologies" free services are used, i.e. Google (Google documents: online word processing program, tabular processor, presentation mode, and a cloud storage service with file exchange tool); and web-oriented software functioning as a web-browser not requiring installation on a user's computer. Also during the learning process students learn to create their own cloud storage in a local network with the help of the OwnCloud service, and study the possibilities of its usage in the learning process and their future professional activities.

Figure 1 presents the possibilities of cloud storage usage. Calendar and scheduler are essential tools for designing an efficient learning process, which enable to organize a schedule, plan fulfillment of tasks and projects; make notes; look through to-do lists and receive proper warnings in due time. The organization of shared access to files of various users is one of the most powerful and convenient mechanisms, which is enabled through the usage of cloud data storage. Teaching staff can allow access to students for their electronic versions of their lectures, laboratory tasks, additional literature and other documents. In a similar way students have an opportunity to interact both with teaching staff and their group mates. The ownCloud users can grant access to a file to a predetermined group of people. The given concept might facilitate students' work over a common academic project or any other activities carried out in groups. The concepts also include an opportunity of file distribution among people not registered in ownCloud system - exchange is performed via public links. The change of record is one of the functions ensuring data integrity. A version of a control subsystem enables users to receive access to old file versions with an opportunity to trace down records of their changes. Students and instructors are able to cancel file updating at any moment and return to the earlier version. Also, when assessing students, a lecturer as an administrator can see which contribution was made by each student during their work on the project, hence they can assess separate student's activities in an unbiased manner. 
At the given moment, we have been considering a possibility for students to carry out cloud computing using the resources of a remote server, so that they could compile a program and receive results not without installing software on their own computers.

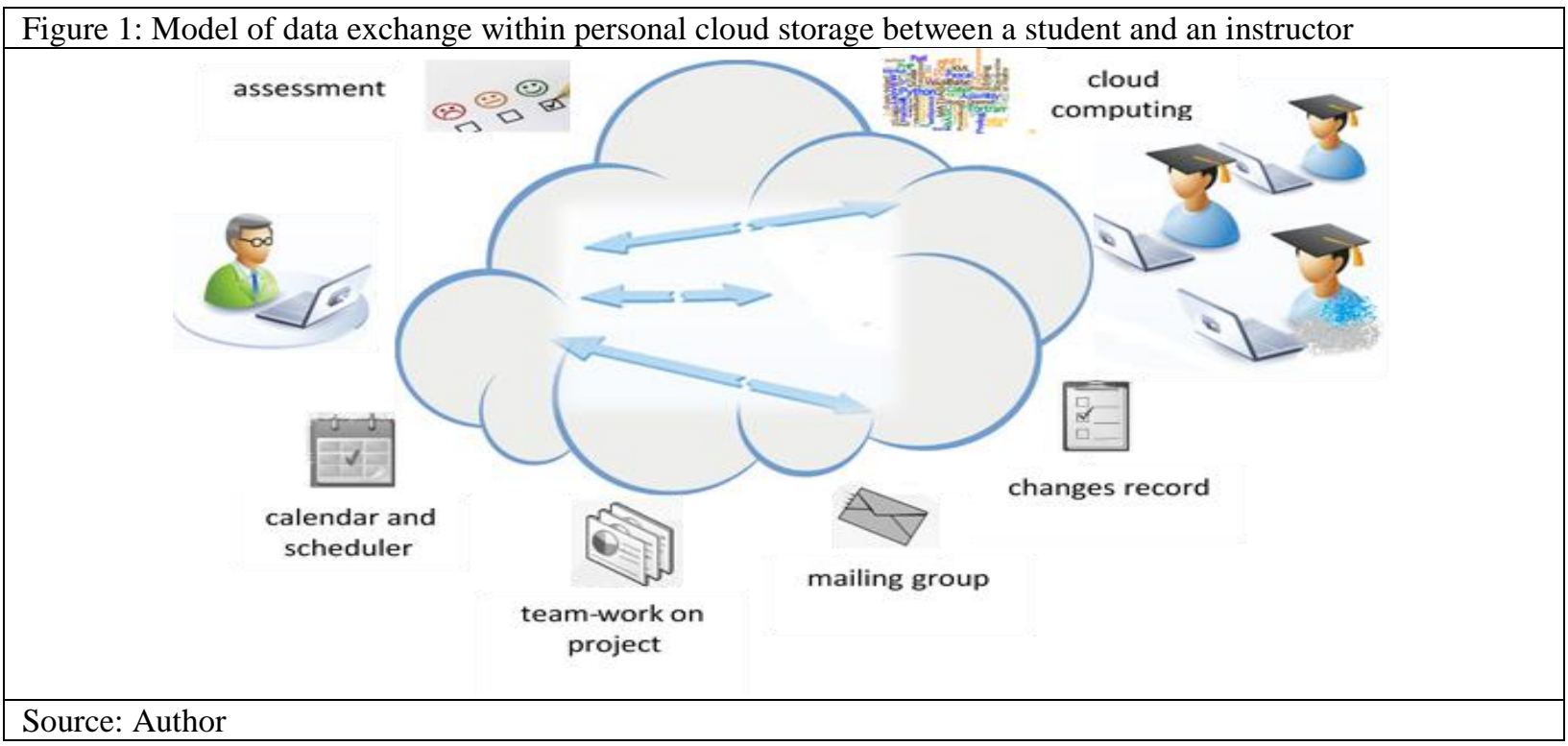

\section{Conclusion}

One of the educational system's tasks in contemporary society is to provide every person with free and open access to education during all life with due regard to their interests, abilities, and demands. Cloud technologies are able to assist in solving those problems since they remove restrictions to usage of operational systems; in fact, with the operating system Linux installed, users can work with any applications and applied programs if they have access to the internet. It can save both material and labor resources.

In the learning process, participants display high interest in some information services, which means that it is advisable to carry out work on introducing cloud technologies into the learning process. Information and communication technologies is a powerful instrument of increasing learning efficiency through the solution of a set of tasks:

1. increase of study hours without changes in curricula;

2. quantitative change in control over students' activities;

3. improvement of information-communicative culture of all the learning process' participants;

4. enhancement of academic motivation among the students;

5. provision of flexibility in learning process management.

\section{References}

Kopyltsov, A. V., Serik, M., \& Bakiyev, M. N. (2014). Modelirovaniye i realizatsiya algoritma otsenivaniya kachestva obucheniya studentov na klastere vysokoproizvoditelnyh parallelnyh vychisleniy. Vestnik ENU, 3 (100)., 147-152.

Kopyltsov, A. V., Lukyanov, G. N., \& Serov I. N. (2010). Modelirovaniye na klastere vysokoproizvoditelnyh parallelnyh vychisleniy vzaimpdeystviya elektromagnitnogo izlucheniya s provodnikooy plastinkoy c samoaffinnym reliefom. Proceedings of the XII Saint-Petersburg International Conference „Regionalnaya informatika-2010“ (pp. 44-49). SanktPeterburg: SPOISU.

Pang, L. (2009). Applying Cloud Computing in the Classroom . Retrieved March 28, 2017, from http://deoracle.org/onlinepedagogy/teaching-strategies/applying-cloud-computing.html

Sarrab, M., Alalwan, N., Alfarraj, O., \& Alzahrani, A. (2015). An empirical study on cloud computing requirements for better mobile learning services. International Journal of Mobile Learning and Organisation, 9(1), 1-20.

Schmidt P. (2016). Bezpečnost' a ochrana údajov z pohl'adu cloud computing. In Ekonomika a informatika, 14 (2), 153-165.

Sklejter, N. (2010). Oblachnye vychisleniya v obrazovanii: Analiticheskaya zapiska. Moskva.

Serik, M., \& Bajgaraeva, A. E. (2014). Nastrojka klastera parallel'nyh vychislenij. Habarshysy Vestnik, 2 (74)., 112-117.

Serik M., Kultan J., \& Sadvakasova A. (2016). Implementation of cloud technology in education process. Journal of knowledge society, 2(4), 88-94.

Voevodin, V. V., \& Zhumatij, S. A. (2007). Vychislitel'noe delo i klasternye sistemy. M.: Izd-vo MGU, 15 